\title{
Chronic pancreatitis is associated with increased concentrations of epidermal growth factor receptor, transforming growth factor $\alpha$, and phospholipase $\mathrm{C} \gamma$
}

\author{
M Korc, H Friess, Y Yamanaka, M S Kobrin, M Buchler, H G Beger
}

\begin{abstract}
The epidermal growth factor (EGF) receptor is a transmembrane protein that binds EGF and transforming growth factor $\alpha$ (TGF $\alpha)$, and that stimulates phospholipase C $\gamma 1$ (PLC $\gamma 1$ ) activity. In this study the role of the EGF receptor in chronic pancreatitis was studied. By immunohistochemistry, the EGF receptor, TGF $\alpha$, and PLC $\gamma 1$ were found to be expressed at high concentrations in pancreatic ductal and acinar cells from chronic pancreatitis patients. Northern blot analysis showed that, by comparison with normal controls, 19 of 27 chronic pancreatitis tissues exhibited a $5 \cdot 7$-fold increase in EGF receptor mRNA concentrations, and 20 of 27 chronic pancreatitis tissues exhibited a sixfold increase in TGF $\alpha$ mRNA concentrations. In situ hybridisation confirmed that overexpression occurred in ductal and acinar cells, and showed that both mRNA moieties colocalised with their respective proteins. These findings suggest that TGF $\alpha$ may act through autocrine and paracrine mechanisms to excessively activate the overexpressed EGF receptor in the two major cell types of the exocrine pancreas, thereby contributing to the pathobiology of this disorder.

(Gut 1994; 35: 1468-1473)
\end{abstract}

Chronic pancreatitis is a debilitating disease of the exocrine pancreas that may be associated with pancreatic exocrine and endocrine insufficiencies. In the Western world, about $70 \%$ of the cases are believed to result from chronic alcohol ingestion. ${ }^{1}$ Additional predisposing causes include cholelithiasis, pancreatic duct obstruction, and hereditary factors. ${ }^{1}$ Histologically, the pancreas in this condition shows areas of fibrosis, inflammatory cell infiltrates, acinar cell degeneration, and dedifferentiation into duct like tubular complexes, and ductal cell proliferation. ${ }^{2-3}$ Although the biochemical and molecular mechanisms that underlie these histological changes are unknown, transgenic mice that overexpress transforming growth factor $\alpha$ (TGF $\alpha$ ) exhibit similar histological changes in the pancreas despite the absence of inflammatory cells. ${ }^{4-6}$ On the basis of these histological similarities it has been suggested that TGF $\alpha$ may contribute to the cellular changes and fibrosis that occurs in chronic pancreatitis in humans. ${ }^{6}$

It is not clear how TGF $\alpha$ overexpression leads to the histological changes that occur in the pancreas of these transgenes. It is established, however, that the first step in the initiation of TGF $\alpha$ action is dependent on its binding to the epidermal growth factor (EGF) receptor. EGF receptor activation leads to a cascade of biochemical reactions, which include the phosphorylation of phospholipase C $\gamma \mathrm{l}$ (PLC $\gamma 1) .{ }^{7}$ The last factor induces the hydrolysis of phosphatidylinositol 4,5-bisphosphate (PIP2), and the generation of diacylglycerol and inositol 1,4,5-trisphosphate (Ins $(1,4,5) P 3) .{ }^{8}$ Diacylglycerol activates protein kinase $C$, whereas Ins $(1,4,5) \mathrm{P} 3$ releases calcium from intracellular stores. ${ }^{9} 10$ It is conceivable that excessive activation of these critical signal transduction pathways may interfere with important cellular functions, thereby causing the histopathological changes that occur in the pancreas of these transgenes. The relevance, however, of the TGF $\alpha$ transgene model to chronic pancreatitis in humans is not known.

In this study we examined the expression of the EGF receptor and TGF $\alpha$ in the pancreas of patients with chronic pancreatitis. Because of the importance of PLC $\gamma 1$ in the mediation of TGF $\alpha$ action, we also studied the distribution of this protein in the pancreas. We now report that the EGF receptor and TGF $\alpha$ are overexpressed in the pancreas of many patients with chronic pancreatitis by comparison with normal human pancreatic tissues, and that this overexpression is associated with increased concentrations of PLC $\gamma 1$.

\section{Methods}

\section{TISSUE SAMPLES}

Normal human pancreatic tissue samples from 17 subjects were obtained through an organ donor programme at the University of Ulm. There were 13 male and four female organ donors, ranging in age from 21 to 55 years, with a median age of 41 years. Chronic pancreatitis tissues were obtained from 27 patients undergoing surgery for chronic pancreatitis. There were 23 male and four female chronic pancreatitis patients, ranging in age from 23 to

\author{
Correspondence to: \\ Endocrinology and \\ Metabolism, Medical \\ Sciences I, C240, University \\ of California, Irvine, \\ Accepted for publication \\ 10 January 1994 \\ Department of \\ Ulm, Ulm, Germany
}


56 years, with a median age of 43 years. In both groups, the tissue samples used for analysis were obtained from the head of the pancreas, and, immediately after surgical removal, either fixed in Bouin solution for 12 to 24 hours or frozen in liquid nitrogen. ${ }^{11}$ The frozen samples were maintained at $-80^{\circ} \mathrm{C}$ until use. All studies were approved by the human subjects committees of the University of California, Irvine, and the University of Ulm, Germany.

Histologically, the chronic pancreatitis was graded independently by a pathologist as being moderate to severe in all the patients. The pancreatic tissue samples contained areas of fibrosis, acinar cell atrophy, and ductal dilatation. Occasionally, small lymphocytic infiltrations were also present.

\section{IMMUNOHISTOCHEMISTRY}

Serial paraffin wax embedded sections $(5 \mu \mathrm{m}$ thick) were subjected to immunostaining, using an avidin-biotinylated immunoperoxidase technique (ABC Kit, Oncogene Sciences Inc, Uniondale, NY), as previously reported. ${ }^{11}$ Optimal results were obtained with the following antibody dilutions: EGF receptor, 1:100; TGF $\alpha$ 1:50. Counterstaining was performed with Mayer's haematoxylin. For immunofluorescent analysis, frozen tissue sections $(10 \mu \mathrm{m}$ thick) were placed in phosphate buffered saline containing $0 \cdot 1 \%$ bovine serum albumin, and incubated for 60 minutes at $23^{\circ} \mathrm{C}$ with the respective primary antibody. ${ }^{11}$ Optimal results were obtained with antibody dilutions of 1:100 for EGF receptor, and 1:20 for PLC $\gamma 1$. After washing to remove unbound antibody, the sections were incubated for 40 minutes at $23^{\circ} \mathrm{C}$ with a $1: 20$ dilution of FITC labelled goat antimouse IgG, and washed with phosphate buffered saline. The coverslips were then mounted on glass slides in Citifluor (Ted Pella Inc, Redding, CA) and viewed with a Nikon Optiphot epifluorescence microscope with $B$ filter composition.

Anti-EGF receptor antibodies were purchased from Sigma Chemical Co (Clone no F4, E3138, St Louis, MO), anti-TGF $\alpha$ antibodies from Oncogene Sciences Inc, and anti-PLC $\gamma 1$ antibodies from Upstate Biotechnology Inc, (Lake Placid, NY). All three antibodies were monoclonal mouse IgG and were raised against human antigens. Specificity of anti-EGF receptor antibodies was verified by preincubation for six hours at $23^{\circ} \mathrm{C}$ with A431 cells, which resulted in complete loss of signal. ${ }^{11}$ Specificities of anti-TGF $\alpha$ antibodies were verified by preincubation for one hour at $37^{\circ} \mathrm{C}$ and 14 hours at $4^{\circ} \mathrm{C}$ with recombinant human EGF (rH-EGF, a gift from Dr C GeorgeNascimento at Chiron Inc, Emmeryville, CA), or recombinant human TGF $\alpha$ (rH-TGF $\alpha$, a gift from Dr $M$ Winkler at Genentech Inc, South San Francisco, CA). ${ }^{11}$ The signal obtained with anti-TGF $\alpha$ antibodies was abolished by incubating antibodies with $\mathrm{rH}-\mathrm{TGF} \alpha$ but not with rH-EGF. ${ }^{11}$

\section{IMMUNOBLOTTING}

Whole pancreas homogenates were prepared from three normal pancreatic tissues obtained from organ donors and from three chronic pancreatitis tissues. ${ }^{11}$ Samples were subjected to $7 \cdot 5 \%$ sodium dodecyl sulphate (SDS)polyacrylamide gel electrophoresis (PAGE), and transferred to nitrocellulose membranes. ${ }^{12} 13$ After washing with $5 \%$ bovine serum albumin, filters were incubated for 18 hours at $4^{\circ} \mathrm{C}$ with the respective primary antibody dilutions (EGF receptor, 1:400; PLC $\gamma 11: 100$ ), as previously reported. ${ }^{11}$ The filters were then washed with a buffer containing $20 \mathrm{mM}$ TRIS (pH 7.5), $500 \mathrm{mM} \mathrm{NaCl}$, and $0.05 \%$ TWEEN-20. ${ }^{11}$ For epidermal growth factor receptor analysis, the filters were incubated sequentially with rabbit antimouse IgG (1:2500 dilution) and ${ }^{125} \mathrm{I}$-protein A $(0.33 \mu \mathrm{Ci} / \mathrm{ml})$, and exposed for 48 to 72 hours at $-80^{\circ} \mathrm{C}$ to Kodak XAR-5 film using intensifying screens. For PLC $\gamma 1$ analysis, the antigen was visualised using avidin-biotinylated immunoperoxidase. ${ }^{14}$ The intensity of the bands was quantitated by laser densitometry. ${ }^{11}$

\section{NORTHERN BLOT ANALYSIS}

Total RNA was extracted in the presence of guanidine isothiocyanate, fractionated on $1.2 \%$ agarose $/ 1.8 \mathrm{M}$ formaldehyde gel, and stained with ethidium bromide to verify RNA integrity and loading equivalency ${ }^{11} 1516$ After transfer onto Gene Screen membranes (Du Pont Inc, Boston, MA), the blots were prehybridised, hybridised, and washed under two high stringency conditions, depending on whether antisense riboprobes or CDNA probes were used, as previously described. ${ }^{11}$ In the case of antisense riboprobes, prehybridisation was for 16 hours at $65^{\circ} \mathrm{C}$ in $50 \%$ formamide, $0.5 \%$ SDS, $5 \mathrm{X}$ SSC ( $1 \mathrm{X} \mathrm{SSC}=150 \mathrm{mM} \mathrm{NaCl}$, $15 \mathrm{mM}$ Na-citrate, $\mathrm{pH} 7 \cdot 0$ ), 5X Denhardt's (1X Denhardt's $=0.02 \%$ ficoll, $0.02 \%$ polyvinylpyrrolidone, and $0.02 \%$ bovine serum albumin), $250 \mu \mathrm{g} / \mathrm{ml}$ salmon sperm DNA, and $50 \mathrm{mM} \mathrm{Na}{ }_{2} \mathrm{PO}_{4}, \mathrm{pH} 6 \cdot 5$. Hybridisation was for 16 hours at $65^{\circ} \mathrm{C}$ in the presence of $1 \times 10^{6}$ $\mathrm{cpm} / \mathrm{ml}$ of the labelled probe, followed by washing at $65^{\circ} \mathrm{C}$ in $1 \mathrm{X} \mathrm{SSPE}(150 \mathrm{mM} \mathrm{NaCl}$, $10 \mathrm{mM} \mathrm{NaH} \mathrm{PO}_{4}$, and $1 \mathrm{mM}$ EDTA) containing $1 \% \mathrm{SDS}$, and at $68^{\circ} \mathrm{C}$ in $0.1 \mathrm{X}$ SSPE containing $1 \%$ SDS. In the case of cDNA probes, prehybridisation was for 16 hours at $42^{\circ} \mathrm{C}$ in a buffer that contained $50 \%$ formamide, $1 \%$ SDS, $0.75 \mathrm{M} \mathrm{NaCl}, 5 \mathrm{mM}$ EDTA, 5X Denhardt's, $10 \%$ dextran sulphate, $100 \mathrm{ug} / \mathrm{ml}$ salmon sperm DNA, and $50 \mathrm{mM}$ $\mathrm{Na}_{2} \mathrm{PO}_{4}, \mathrm{pH} 7 \cdot 4$. Hybridisation was for 16 hours at $42^{\circ} \mathrm{C}$ with prehybridisation buffer containing the labelled cDNA probe $\left(5 \times 10^{5}\right.$ $\mathrm{cpm} / \mathrm{ml}$ ). Filters were then washed at $23^{\circ} \mathrm{C}$ in $2 \mathrm{X} \mathrm{SSC} / 1 \% \mathrm{SDS}$, and at $55^{\circ} \mathrm{C}$ in $0.2 \mathrm{X}$ $\mathrm{SSC} / 2 \%$ SDS. The blots were exposed at $-80^{\circ} \mathrm{C}$ to Kodak XAR-5 film with intensifying screens, and the intensity of the radiographic bands was quantified by laser densitometry. ${ }^{11}$

A $0 \cdot 86-\mathrm{kb}$ BamHI/Eco RI fragment of human EGF receptor HER pA2 $1 \mathrm{cDNA}^{17}$ and 


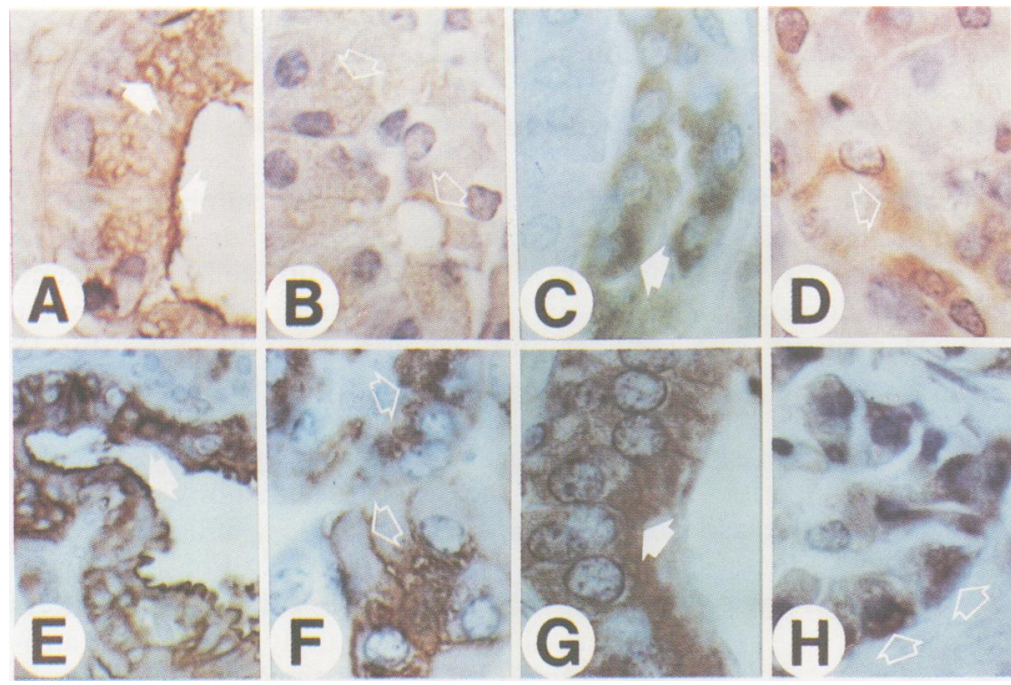

Figure 1: Immunohistochemical staining. Normal ducts $(A, C)$ and acini $(B, D)$ and chronic pancreatitis ducts $(E, G)$ and acini $(F, H)$ exhibited immunostaining for the $E G F$ receptor $(A-B, E-F)$, and TGF $\alpha(C-D, G-H)$, as shown by solid (ductal cells) and open (acinar cells) arrows. Original magnification $\times 250$.

a $1.3 \mathrm{~kb}$ Eco RI fragment of human TGF $\alpha$ cDNA $^{18}$ were subcloned into the pGem 3 plasmid vector, and used to prepare cRNA probes. ${ }^{11}$ In addition, two cDNA probes were used for filter hybridisations: a $1 \cdot 2 \mathrm{~kb}$ Pst I fragment of mouse amylase $\mathrm{cDNA}^{19}$ that cross hybridises with human amylase, and a $0.19 \mathrm{~kb}$ Bam HI fragment of the mouse $7 \mathrm{~S} \mathrm{cDNA}^{20}$ that cross hybridises with human 7S RNA. cDNA probes were labelled with $\alpha{ }^{32} \mathrm{P}$-dCTP (3000 Ci/mmol, Amersham Co, Arlington Heights, IL) to a specific activity of $0.5 \times 10^{9}$ $\mathrm{cpm} / \mu \mathrm{g} .{ }^{11}$ Antisense probe synthesis was carried out with $\alpha{ }^{32} \mathrm{P}-\mathrm{CTP}(3000 \mathrm{Ci} / \mathrm{mmol}$, Amersham (o), to a specific activity of 0.8 to $1.0 \times 10^{9} \mathrm{cpm} / \mu \mathrm{g} .^{11}$

\section{IN SITU HYBRIDISATION}

Tissue sections were placed on slides coated with poly-L-lysine, deparaffinised, and treated for 10 minutes with $1 \mu \mathrm{g} / \mathrm{ml}$ proteinase $\mathrm{K}$ (Boehringer Mannheim Biochemicals, Indianapolis, $\mathrm{IN}$ ), as previously described. ${ }^{11}$ Sections were then incubated for 10 minutes with $0.5 \times$ SSC, and for three hours at $42^{\circ} \mathrm{C}$ in hybridisation buffer, which contained $0.3 \mathrm{M} \mathrm{NaCl}, 20 \mathrm{mM}$ TRIS, $\mathrm{pH} 8 \cdot 0$, $5 \mathrm{mM}$ EDTA, $50 \%$ formamide, $1 \mathrm{X}$ Denhardt's, $10 \%$ dextran sulphate, and $10 \mathrm{mM}$ dithiothreitol. ${ }^{11} 21$ Hybridisation with the above EGF receptor and TGF $\alpha$ antisense probes was performed overnight at $50^{\circ} \mathrm{C}$ with $100 \mu \mathrm{l}$ of buffer containing $100000 \mathrm{cpm}$ of the probe and $50 \mu \mathrm{g}$ of yeast tRNA (GIBCO BRL Inc, Gaithersburg, MD). The sections were digested with RNAse A $(20 \mu \mathrm{g} / \mathrm{ml}$; Sigma Chemical Co) for 30 minutes at $23^{\circ} \mathrm{C}$, washed, dehydrated by immersion in graded alcohol containing $0.3 \mathrm{M}$ ammonium acetate, dried, coated with NTB2 emulsion (Eastman Kodak Co, Rochester, NY), and exposed for five days. ${ }^{11}$ Pretreatment of the slides with RNAse abolished the hybridisation signals, and sense probes corresponding to the antisense probes failed to produce a signal. The slides were counterstained with Mayer's haematoxylin.

Quantitative analysis of the in situ hybridisation data was performed with a dark field filter using a Nikon Diaphot microscope and Nikon FX microscopic photometric system (Tokyo, Japan) equipped with a video camera and an Image 1 video image analysis system (Universal Imaging Co, Media, PA). Images were routinely scanned for average pixel intensity and background density, which allows for computer based correction of uneven image illumination, as previously reported. ${ }^{11}$ Densitometric analysis of the silver grains was performed under $400 \times$ magnification in 12 fields per slide that were randomly selected, using five normal tissues and five chronic pancreatitis tissues. The data were then expressed as a percentage of the area occupied by the silver grains in a total area of each field.

\section{STATISTICAL ANALYSIS}

Data were analysed by Student's $t$ test, using the StatView 512 computer program (Brainpower Inc, Calabasas, CA).

\section{Results}

In the normal human pancreas, EGF receptor immunoreactivity was present on the apical surface of ductal cells and, to a lesser extent, in the cytoplasm of these cells in most ductules and intralobular ducts (Fig 1A), as well as on the surface and in the cytoplasm of many acinar cells (Fig 1B). TGF $\alpha$ immunoreactivity was also present on the surface and in the cytoplasm of both ductal (Fig 1C) and acinar (Fig 1D) cells. In the chronic pancreatitis tissues, the intensity of the immunoreactivity for the EGF receptor (Fig 1E-F) and TGF $\alpha$ (Fig 1G-H) was considerably increased in the acinar and ductal cells. In the case of TGF $\alpha$, cytoplasmic immunoreactivity was especially
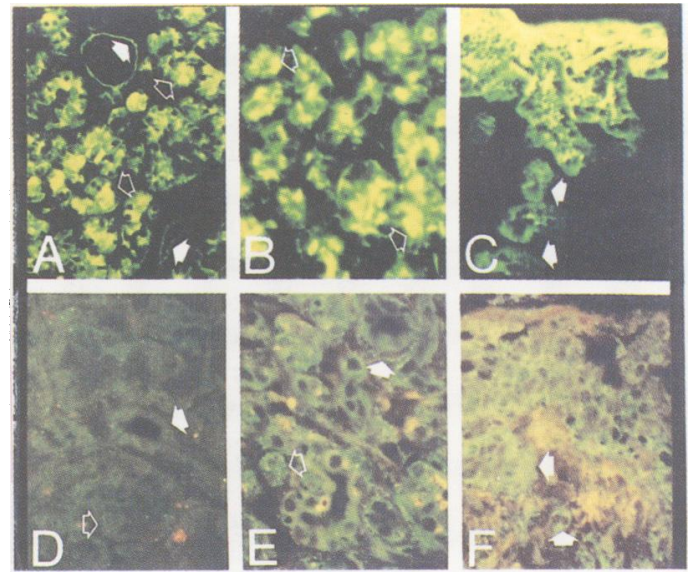

Figure 2: Immunofluorescent staining. Immunofluorescence of $E G F$ receptor in normal $(A)$ and chronic pancreatitis $(B-C)$ tissue samples, showing staining in acinar (open arrows) and ductal (solid arrows) cells. The upper portion of panel $C$ illustrates a large duct whose cells exhibit considerable immunofluorescense for the EGF receptor. Immunofluorescence of PLC $\gamma 1$ in normal (D) and chronic pancreatitis $(E-F)$ tissue samples, showing staining in acinar (open arrows) and ductal (solid arrows) cells. Original magnification $\times 100$. 


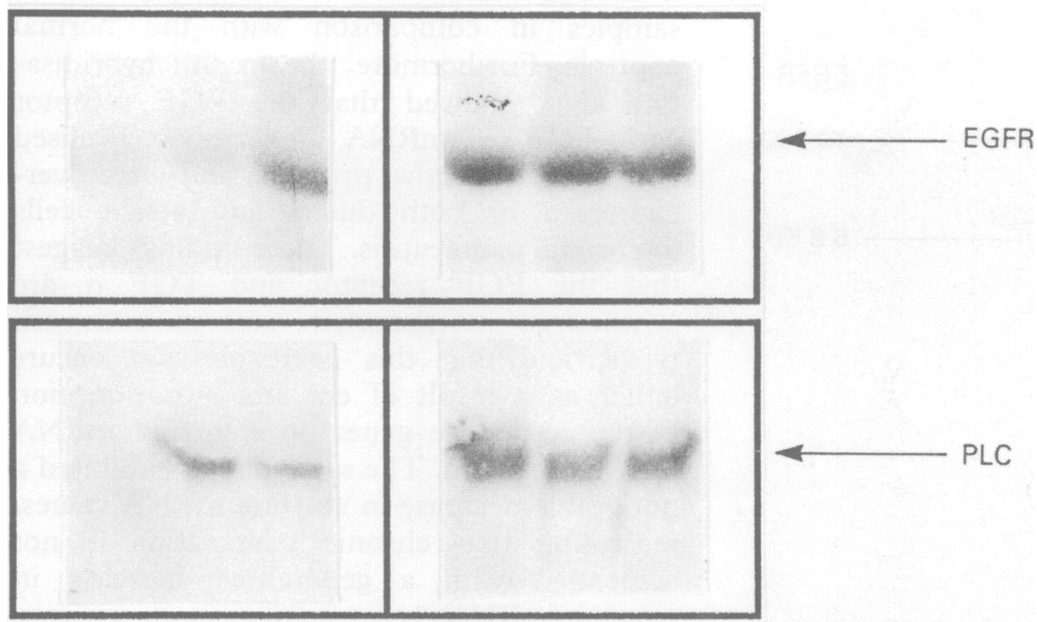

Figure 3: EGF receptor and PLC $\gamma 1$ immunoblotting. Homogenates from normal and chronic pancreatitis tissue samples were subjected to SDS-PAGE electrophoresis followed by immunoblotting with specific monoclonal anti-EGF receptor (EGFR) and anti-PLC $\gamma 1$ (PLC) antibodies, as described in the methods section. Each lane represents $100 \mu \mathrm{g}$ of protein. Autoradiograph exposure times was 72 hours for the EGF receptor. PLC y1 was visualised with avidin-biotinylated immunoperoxidase.

prominent at the basal aspect of the acinar cells (Fig 1H). EGF receptor and TGF $\alpha$ immunoreactivity was not seen in the stroma surrounding the acinar and ductal cells.

Immunofluorescent staining showed diffuse cellular distribution of EGF receptor in acinar cells and apical distribution in ductal cells in the normal human pancreas (Fig 2A), and diffuse but faint distribution of PLC $\gamma 1$ in both cell types (Fig 2D). In the chronic pancreatitis tissues there was diffuse and intense distribution of EGF receptor in the remaining acini (Fig 2B) and in the ductal cells (Fig 2C), and intense PLC $\gamma 1$ staining in the same regions (Fig 2E-F). The increase in immunofluorescent staining was especially noticeable in regions exhibiting multiplayered ductal epithelial hyperplasia (Fig 2C, F).

When equal amounts of protein from three normal and three chronic pancreatitis tissue samples were subjected to immunoblotting with the respective antibodies, there was a threefold increase in EGF receptor and PLC $\gamma 1$ values in the chronic pancreatitis samples in comparison with the normal controls (Fig 3), as assessed by densitometric analysis. Thus, in the case of the EGF receptor, the optical density values (mean (SEM)) for the normal and chronic pancreatitis tissue samples were $0.77(0.17)$ and $2.39(0.19)$ respectively $(\mathrm{p}<0.005)$. In the case of PLC $\gamma 1$, these values were $0.28(0.15)$ and $0.82(0.08)$ respectively $(\mathrm{p}<0.05)$.

Northern blot analysis showed the presence of low concentrations of EGF receptor and TGF $\alpha$ mRNA and high concentrations of amylase $\mathrm{mRNA}$ in the normal human pancreas (Fig 4). In the chronic pancreatitis samples, EGF receptor and TGF $\alpha$ mRNA values were raised by comparison with the normal controls, in association with a considerable decrease in amylase mRNA values (Fig 4). Densitometric analysis showed that, by comparison with normal controls, 19 of 27 chronic pancreatitis tissues exhibited a $5 \cdot 7$-fold increase in EGF receptor mRNA values, and 20 of 27 chronic pancreatitis tissues exhibited a sixfold increase in TGF $\alpha$ mRNA values (Table). EGF receptor and TGF $\alpha$ mRNA values were significantly greater by comparison with the corresponding values in the normal control values even when the data from all the chronic pancreatitis samples were pooled together (Table).

In situ hybridisation with antisense probes showed the presence of specific grains corresponding to EGF receptor $\mathrm{mRNA}$ in the ductal (Fig 5A) and acinar (Fig 5B) cells of the normal human pancreas. In both cell types, the grains corresponding to TGF $\alpha$ mRNA were present at comparatively high values (Fig 5C-D). Both mRNA species preferentially localised at the apical portion of the ductal cells, and at the basal portion of the acinar cells. In the chronic pancreatitis tissue samples, there was a readily evident increase in EGF receptor and TGF $\alpha$ RNA grains in both the ductal cells and the remaining acinar cell (Fig 5E-H).

Quantitative videoimage analysis of the in situ hybridisation data from five normal and five chronic pancreatitis tissue samples showed that there were 23-fold and fourfold increases in the mRNA values encoding the EGF receptor and TGF $\alpha$, respectively, in the chronic pancreatitis tissues by comparison with the normal pancreas. As in the case of the immunostaining, however, neither mRNA moiety was found in the stroma.

\section{Discussion}

In this study, we have determined that the EGF receptor and TGF $\alpha$ are overexpressed in human pancreatic tissues obtained from patients with chronic pancreatitis. Immunohistochemically, this overexpression was evident in both the remaining acinar cells and in the ductal cells. In contrast, neither protein was detected in the stroma. In the acinar cells, EGF receptor immunostaining was pronounced on the surface and in the cytoplasm, whereas TGF $\alpha$ immunoreactivity was most notable in the cytoplasm. In the ductal cells, the immunostaining for both proteins was noticeably increased, especially in regions exhibiting multilayered ductal epithelial hyperplasia. In these regions, cell surface EGF receptor immunoreactivity was pronounced throughout the epithelial cell layers.

In both the acinar cells and duct cells, EGF receptor overexpression was associated with increased values of a key regulatory enzyme that is a substrate for EGF receptor action, PLC $\gamma 1$, as determined by immunofluorescence. The increase in PLC $\gamma 1$ values was confirmed by immunoblotting. The importance of this enzyme is underscored by the fact that activation of several transmembrane tyrosine kinase receptors that regulate cell proliferation leads to the association of PLC $\gamma 1$ with their tyrosine kinase domains, ${ }^{22} 23$ and by the ability of PLC $\gamma 1$ to regulate several important 


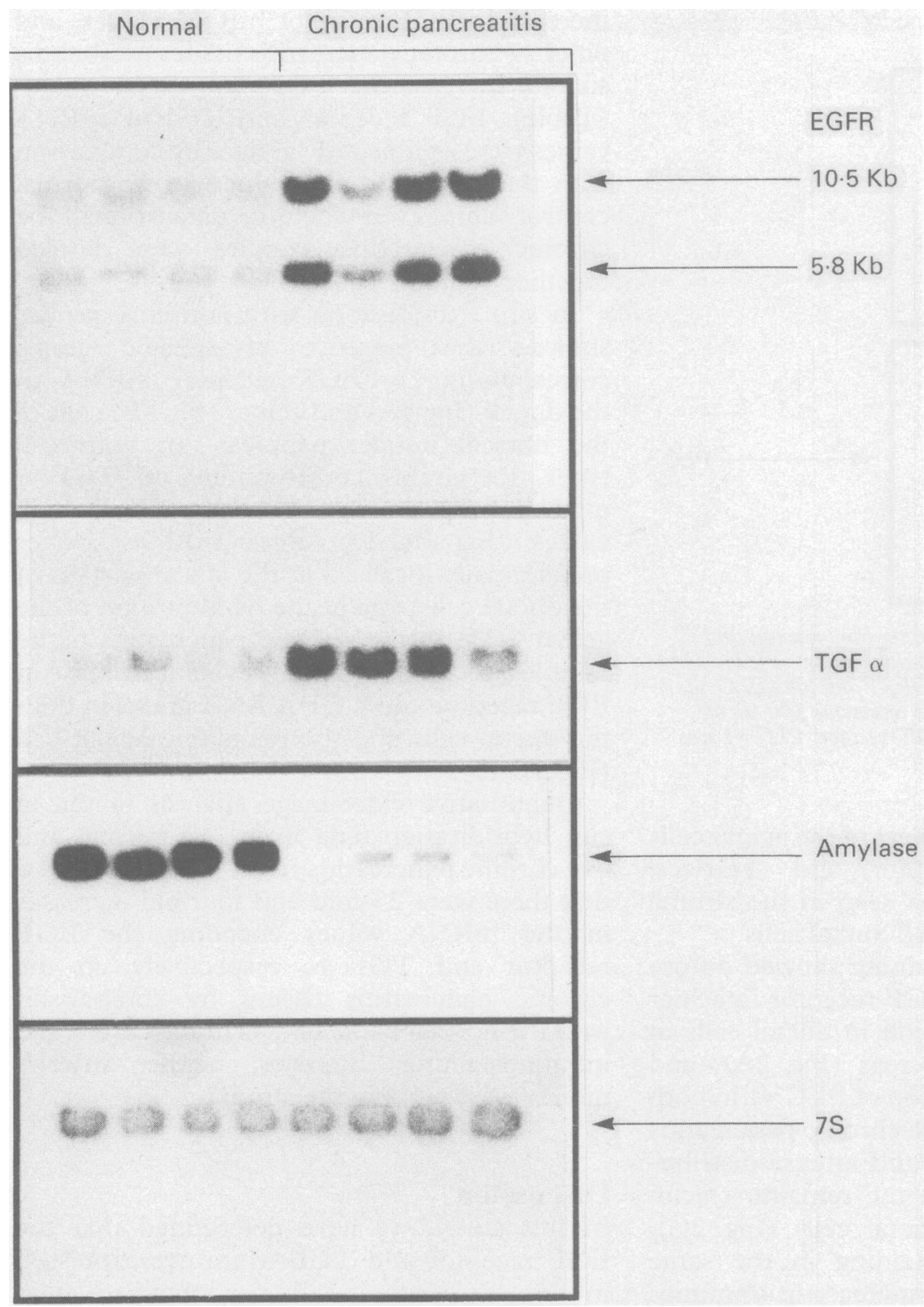

Figure 4: Analysis of EGF receptor and TGF $\alpha m R N A$ values. Immobilised $R N A$ from normal and chronic pancreatitis tissues was hybridised with the indicated probes as follows: EGF receptor ( $4 \times 10^{5} \mathrm{cpm} / \mathrm{ml}$; eight day exposure); TGF $\alpha\left(2 \times 10^{5} \mathrm{cpm} / \mathrm{ml}\right.$; two day exposure); amylase (105 cpm/ $\mathrm{ml}$; one day exposure); and $7 S \mathrm{cDNA}\left(5 \times 10^{4} \mathrm{cpm} / \mathrm{ml} ; 12\right.$ hour exposure). The EGF receptor mRNA migrated as two bands (10.5 and 5.8 kilobase); TGF $\alpha$ mRNA migrated as a 4.6 kilobase band; amylase mRNA migrated as a 1.8 kilobase band; the $7 S$ mRNAs migrated as a 0.4 kilobase species.

signal transduction pathways. ${ }^{8-10}$ A similar correlation between EGF receptor overexpression and increased PLC $\gamma 1$ values has been reported in breast cancers ${ }^{24}$ and psoriatic skin lesions. ${ }^{25}$ Taken together, these findings suggest that PLC $\gamma 1$ dependent pathways play a part in both benign and malignant proliferative conditions.

Both by northern blot analysis of total RNA and by morphometric analysis of the in situ hybridisation data there were statistically

Densitometric analysis of northern blots

\begin{tabular}{lllll}
\hline & \multicolumn{4}{l}{ Relative optical density } \\
\cline { 2 - 5 } & EGFR/7S & No of samples & TGF $\alpha / 7 S$ & No of samples \\
\hline Normal & $10 \cdot 9(1 \cdot 7)$ & 17 & $30 \cdot 4(5 \cdot 6)$ & 17 \\
All CPS & $44 \cdot 2(8 \cdot 1)^{\star}$ & 27 & $150 \cdot 7(28 \cdot 3)^{\star \star}$ & 27 \\
CPS with increased RNA values & $61 \cdot 8(8 \cdot 7)^{\star \star}$ & 19 & $183 \cdot 5(25 \cdot 8)^{\star \star}$ & 20 \\
\hline
\end{tabular}

EGF receptor, TGF $\alpha$, and 7S autoradiographs were analysed by laser densitometry. Values are the mean (SEM) from the number of normal and chronic pancreatitis samples (CPS).

EGFR/7S: ratio of EGF receptor to $7 S$ signal. TGF $\alpha / 7 S$ : ratio of TGF $\alpha$ to $7 S$ signal. ${ }^{*} p<0.02$, ${ }_{\star \star} \mathrm{p}<0.001$, when compared with respective controls. significant increases in EGF receptor and TGF $\alpha$ mRNA values in the chronic pancreatitis samples in comparison with the normal controls. Furthermore, the in situ hybridisation data showed that the EGF receptor and TGF $\alpha$ mRNA moieties colocalised with their respective proteins, and were overexpressed in both ductal and acinar cells in chronic pancreatitis. These findings suggest that the EGF receptor and TGF $\alpha$ are synthesised at increased rates in both cell types, and that this overexpression occurs either as a result of enhanced transcription of the respective genes or increased mRNA stability, or both. The same tissues exhibited a noticeable decrease in amylase mRNA values, indicating that chronic pancreatitis is not associated with a generalised increase in pancreatic RNA.

In this study we could not investigate whether there was a correlation between the severity of the chronic pancreatitis and the levels of expression of the EGF receptor and TGF $\alpha$, as only patients with severe disease had pancreatic resection. Therefore, all the samples that were available for analysis exhibited moderate to severe disease histological changes. The fact that this overexpression occurred, however, in both acinar cells and ductal cells suggests that TGF $\alpha$ may excessively activate the EGF receptor through autocrine and paracrine mechanisms in both cell types. TGF $\alpha$ may thus be able to enhance duct cell proliferation, modulate acinar cell function, exert chemotactic effects on fibroblasts, and enhance collagen production by fibroblasts. These effects of TGF $\alpha$ may explain, in part, the fibrosis that occurs in chronic pancreatitis. In support of this hypothesis, the EGF receptor and TGF $\alpha$ are overexpressed in human pancreatic cancer, ${ }^{11}$ a condition that is also associated with ductal cell proliferation and extensive fibrosis. Furthermore, in transgenic mice that overexpress TGF $\alpha$ the pancreas exhibits histological changes that mimic those seen in chronic pancreatitis. ${ }^{4-6}$ These changes include acinar cell degeneration and dedifferentiation into duct like cells and considerable fibrosis. ${ }^{4-6}$ Interestingly, in some of these transgenes there is an appreciable increase in type I collagen in the pancreas, and the collagen fibres seem to preferentially associate with the basal aspect of the TGF $\alpha$ expressing acinar cells. ${ }^{6}$ It will be important to find out in future studies if a similar distribution of type I collagen occurs in chronic pancreatitis in humans.

Transfection experiments show that overexpression of the EGF receptor or TGF $\alpha$ leads to malignant transformation. ${ }^{26} 27$ Therefore, the concomitant overexpression of the receptor and its ligand reported in this study may explain the epidemiological data, which show a slight increase in the frequency of pancreatic adenocarcinomas in patients with chronic pancreatitis. ${ }^{28-30}$ Cancer, however, is a multistage process. As many as $90 \%$ of human pancreatic cancers exhibit mutations in the $\mathrm{K}$-ras oncogene. ${ }^{31}$ 32. These tumours are also associated with a significant incidence of 


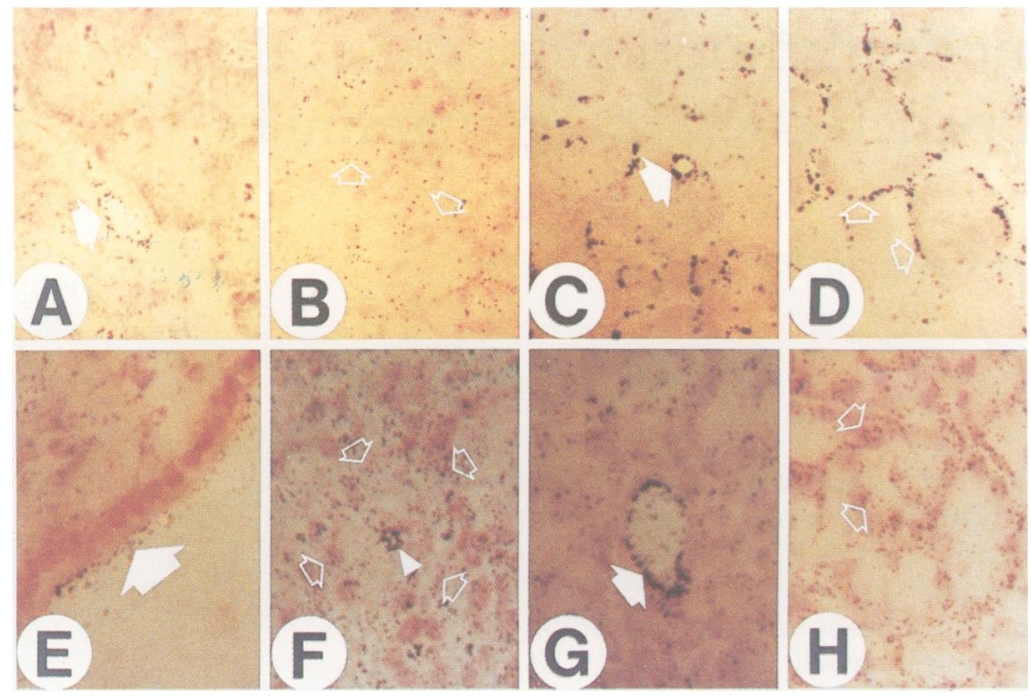

Figure 5: In situ hybridisation. Detection of $E G F$ receptor $(A-B, E-F)$, and TGF $\alpha$ $(C-D, G-H) m R N A$ in situ hybridisation grains with antisense probes in normal ducts $(A, C)$ and acini $(B, D)$ and chronic pancreatitis ducts $(E, G)$ and acini $(F, H)$, as shown by solid (ductal cells) and open (acinar cells) arrows. Arrowhead ( $F$ ) points to apical lumen of an acinus. Original magnification $\times 100$; exposure time: five days.

mutations in the p53 tumour suppressor gene. $^{33} 34$ In contrast, p53 mutations do not occur in chronic pancreatitis. ${ }^{34}$ Thus, in the absence of other perturbations, overexpression of the EGF receptor and TGF $\alpha$, may not be sufficient to induce pancreatic malignant transformation. In contrast, when combined with certain gene mutations, overexpression of the EGF receptor and $\mathrm{TGF} \alpha$ may lead to accelerated tumour progression and abnormal cellular proliferation. This study was supported by Public Health Service Grant
CA-40162 awarded by the National Cancer Institute to CA-40162
M Korc.

A portion of this work was presented at the United European Gastroenterology Meeting, July 1993.

1 Sarles H, Bernard JP, Johnson C, Chir M. Pathogenesis and epidemiology of chronic pancreatitis. Ann Rev Med 1989; 40: 453-68.

2 Oertel JE, Heffess CS, Oertel YC. Pancreas. In: Sternberg SS, ed. Diagnostic surgical pathology. New York: Raven Press, 1989: 1057-93.

3 Kennedy RH, Bockman DE, Uscanga L, Choux R, Grimaud JA, Sarles H. Pancreatic extracellular matrix alterations in chronic pancreatitis. Pancreas 1987; 2: 61-72.

4 Sandgren EP, Luetteke NC, Palmiter RD, Brinster RL, Lee DC. Overexpression of TGF- $\alpha$ in transgenic mice: inducDC. Overexpression of TGF- $\alpha$ in transgenic mice: induc-
tion of epithelial hyperplasia, pancreatic metaplasia, and tion of epithelial hyperplasia, pancreatic metaplasia

5 Jhappan C, Stahle C, Harkins RN, Fausto N, Smith GH, Merlino GT. TGF- $\alpha$ overexpression in transgenic mice induces liver neoplasia and abnormal development of the mammary gland and pancreas. Cell 1990; 61: 1137-46.

6 Bockman DE, Merlino GT. Cytological changes in the pancreas of transgenic mice overexpressing transforming growth factor- $\alpha$. Gastroenterology 1992; 103: 1883-92.

7 Meisenhelder J, Suh P-G, Rhee SG, Hunter T. Phospholipase C- $\gamma$ is a substrate for the PDGF and EGF receptor protein-tyrosi

8 Berridge MJ, Irvine RF. Inositol phosphates and cell signalling. Nature 1989; 341: 197-205.

9 Nishizuka Y. The molecular heterogeneity of protein kinase $\mathrm{C}$ and its implications for cellular regulation. Nature 1988 ; 334: 661-5.

10 Guillemette G, Balla T, Baukal AJ, Catt KJ. Inositol 1,4,5trisphosphate binds to a specific receptor and releases microsomal calcium in the anterior pituitary gland. Proc Natl Acad Sci USA 1987; 84: 8195-9.

11 Korc M, Chandrasekar B, Yamanaka Y, Friess H, Buchler $M$, Beger HG. Overexpression of the epidermal growth actor receptor in human pancreatic cancer is associated with concomitant increases in the levels of epidermal growth factor and transforming growth factor alpha. f Clin Invest 1992; 90: 1352-60.

12 Laemmli UK. Cleavage of structural proteins during the assembly of the head of bacteriophage T4. Nature 1977; 227: $680-5$.

13 Towbin H, Staehelin T, Gordon J. Electrophoretic transfer of proteins from polyacrylamide gels to nitrocellulose sheets: procedure and some applications. Proc Natl Acad Sci USA 1979; 76: 4350-4.

14 Torti M, Lapetina EG. Role of rap1B and p21 ras GTPaseactivating protein in the regulation of phospholipase 1992; 89: 7796-800.

15 Glinsmann-Gibson BJ, Korc M. Regulation of transforming growth factor- $\alpha$ mRNA expression in $T_{3} M_{4}$ human pancreatic carcinoma cells. Pancreas 1991; 6: 142-9.

16 Chang SP, Brannon M, Korc M. Effects of dietary manganese deficiency on rat pancreatic amylase mRNA levels. f Nutr 1990; 120: 1228-34

17 Ullrich A, Coussens L, Hayflick JS, Dull TJ, Gray A, Tam AW, et al. Human epidermal growth factor receptor cDNA sequence and aberrant expression of the amplified gene in A431 epidermoid carcinoma cells. Nature 1984; 309: $418-25$.

18 Derynck R, Robert AB, Winkler ME, Chen EY, Goeddel DV. Human transforming growth factor- $\alpha$ : precursor structure and expression in $\mathrm{E}$ coli. Cell 1984; 38: 287-97.

19 Schibler U, Tosi M, Pittet AC, Fabiani L, Wellauer PK. Tissue-specific expression of mouse $\alpha$-amylase genes. f Mol Biol 1980; 142: 93-116.

20 Balmain A, Krumlauf R, Vass JK, Birnie GD. Cloning and characterization of the abundant cytoplasmic 7S RNA from mouse cells. Nucleic Acids Res 1982; 10: 4259-77.

21 Wilcox JN, Smith KM, Williams LT, Schaluartz SM, Gordon D. Platelet-derived growth factor mRNA detection in human atherosclerotic plaques by in situ hybridization. $\mathcal{F}$ Clin Invest 1988; 82: 1134-43.

22 Margolis B, Bellot AM, Honegger AM, Ullrich A, Schlessinger J, Zilberstein A. Tyrosine kinase activity is essential for the association of phospholipase C- $\gamma$ with EGF receptor. Mol Cell Biol 1990; 10: 435-41.

23 Kumjian DA, Barnstein A, Rhee SG, Daniel TO. Phospholipase C- $\gamma$ complexes with ligand-activated Phospholipase $\mathrm{C}-\gamma$ complexes with ligand-activated
platelet-derived growth factor receptors. An intermediate implicated in phospholipase activation. $\mathcal{F}$ Biol Chem 1991; 266: 3973-80.

24 Arteaga CL, Johnson MD, Todderud G, Coffey RJ, Carpenter G, Page DL. Elevated content of the tyrosine kinase substrate phospholipase C- $\gamma 1$ in primary human breast carcinomas. Proc Natl Acad Sci USA 1991; 88: 10435-9.

25 Nanney LB, Yates RA, King LE Jr. Modulation of epidermal growth factor receptors in psoriatic lesions during treatment with topical EGF. F Invest Dermatol 1992; 98: treatment

26 Di Fiore PP, Pierce JH, Fleming TP, Hazan R, Ullrich A King CR, et al. Overexpression of the human EGF receptor confers an EGF-dependent transformed phenotype to NIH 3T3 cells. Cell 1987; 51: 1063-70.

27 Watanabe S, Lazar E, Sporn MB. Transformation of normal rat kidney (NRK) cells by an infectious retrovirus carrying a synthetic rat type $\alpha$ transforming growth factor gene. Proc Natl Acad Sci USA 1987; 84: 1258-62.

28 Lowenfels AB, Maisonneuve P, Cavallini G, Ammann RW, Lankisch PG, Andersen JR, et al. Pancreatitis and the risk of pancreatic cancer. $N$ Engl f Med 1993; 328: 1433-7.

29 Lin JT, Wang TH, Chen DS, How SW, Lai MY, Chen JC, et al. Pancreatic carcinoma associated with chronic calcifying pancreatitis in Taiwan: a case report and review of the literature. Pancreas 1988; 3: 111-4.

30 Haas O, Guillard G, Rat P, Friedman S, Favre JP. Pancreatic carcinoma developing in chronic pancreatitis: a report of four cases. Hepatogastroenterology 1990; 37: $350-1$

31 Almoguera C, Shibata D, Forrester K, Martin J, Perucho $M$. Most human carcinomas of the exocrine pancreas contain mutant c-K-ras genes. Cell 1988; 53: 549-54

32 Grunewald K, Lyons J, Frohlich A, Feichtinger H, Weger $\mathrm{RA}$, Schwab G, et al. High frequency of Ki-ras codon 12 mutations in pancreatic adenocarcinomas. Int $\mathcal{f} \mathrm{Cancer}$ 1989; 43: 1037-41.

33 Barton CM, Staddon SL, Hughes CM, Hall PA, O'Sullivan $\mathrm{C}$, Kloppel G, et al. Abnormalities of the p53 tumour suppressor gene in human pancreatic cancer. $\mathrm{Br} f \mathrm{Cancer}$ 1991; 64: 1076-82.

34 Graham C, Yamanaka Y, Friess H, Kobrin MS, Lopez ME Buchler M, et al. p53 mutations are common in pancreatic cancer and are absent in chronic pancreatitis. Cancer Lett 1993; 69: 151-60. 